\title{
Perforation of the sigmoid colon secondary to endometriosis. Case report
}

\author{
Perforación de colon sigmoides secundaria a endometriosis. Reporte de un caso
}

\author{
Ernesto A. Dzib-Calan ${ }^{*}$, Jorge I. Morales-Pérez', Juan C. Aranda-Puebla², Álex Simón-Mendoza², \\ Gerardo Rodarte-Cajica ${ }^{2}$ and Gustavo Leal-Mérida ${ }^{3}$ \\ ${ }^{1}$ Postgraduate Naval School of Public Health; ' ${ }^{2}$ General Surgery Department; ${ }^{3}$ Surgical Areas. Hospital General Naval de Alta Especialidad, Mexico \\ City, Mexico
}

\begin{abstract}
Background: Endometriosis is the presence of endometrial glands or viable stroma outside the uterine cavity, which affects approximately $2-10 \%$ of women of reproductive age 1. Pelvic structures, including the bowel, are commonly affected. Perforation of the colon by endometriosis is very rare and represents a surgical emergency. Clinical case: A 28-year-old female patient with abdominal pain in the right iliac fossa and pelvic cavity, fever and nausea, exploratory laparotomy is performed with the discovery of sigmoid perforation of the colon, requiring resection of the lesion and terminal colostomy, finding as definitive diagnosis endometriosis. Conclusion: Bowel or colon perforation is a rare but serious complication, which should always be kept in mind as a suspicion of acute abdomen in a female patient of reproductive age and with a history of intermittent gastrointestinal symptoms.
\end{abstract}

KEY WORDS: Endometriosis. Intestine. Colon. Perforation.

\section{Resumen}

Antecedentes: La endometriosis es la presencia de glándulas endometriales o estroma viable fuera de la cavidad uterina, que afecta aproximadamente al 2-10\% de las mujeres en edad reproductiva ${ }^{1}$. Es común la afección de estructuras pélvicas, incluyendo el intestino. La perforación del colon por endometriosis es muy rara y representa una urgencia quirúrgica. Caso clínico: Mujer de 28 años con cuadro de dolor abdominal en fosa iliaca derecha y hueco pélvico, fiebre y náuseas. Se realiza laparotomía exploradora con hallazgo de perforación de colon sigmoides, que requiere resección de la lesión y colostomía terminal, encontrando como diagnóstico definitivo endometriosis. Conclusión: La perforación de intestino o de colon es una complicación poco frecuente, pero de gravedad, que debemos tener siempre presente como sospecha ante un cuadro de abdomen agudo en una paciente en edad fértil y con antecedentes de haber presentado sintomatología gastrointestinal intermitente.

PALABRAS CLAVE: Endometriosis. Intestino. Colon. Perforación.

\author{
Correspondence: \\ ${ }^{*}$ Ernesto A. Dzib-Calan \\ Av. Heroica Escuela Naval Militar, edif. 1, depto. 302 \\ Col. Presidentes Ejidales 2da. secc. \\ Del. Coyoacán, C.P. 04470, Ciudad de México, México \\ E-mail: eangel_dc@ @otmail.com
}

Date of reception: 14-03-2018

Date of acceptance: 21-04-2018

DOI: 10.24875/CIRUE.M18000055
Cir Cir. 2018;86:333-335

Contents available at PubMed www.cirugiaycirujanos.com 


\section{Introduction}

Endometriosis is the presence of endometrial glands or viable stroma outside the uterine cavity, which affects approximately $2-10 \%$ of women of childbearing age ${ }^{1}$. Involvement of pelvic structures, including the intestine is common.

The prevalence of intestinal endometriosis ranges from 5.3 to $12 \%$. The rectum and the sigmoid colon are the most affected structures, with the ileum being most rarely compromised ${ }^{2}$. Average age at diagnosis is 34-40 years ${ }^{3}$. Endometriosis-associated colon perforation is very rare and patients generally are asymptomatic or have a painful pelvic mass in the left iliac fossa. The lack of pathognomonic signs and symptoms makes intestinal endometriosis a disease that is difficult to suspect of and rarely preoperatively diagnosed. Differential diagnoses include irritable bowel syndrome, infectious diseases, mesenteric ischemia, Crohn's disease and neoplasm ${ }^{4}$.

\section{Clinical case}

Twenty-eight-year-old woman with a surgical history of cesarean section 2 years prior for acute fetal distress, last menstrual period (LMP) 15 days prior to admission, and no chronic degenerative diseases, who had attended the emergency department with a 7-day history of abdominal colic-type pain localized at the hypogastrium and right iliac fossa, with $7 / 10$ intensity assessed with the analogue pain scale, without other accompanying symptoms, which was managed on an outpatient basis with butylhyoscine, metamizole, lysine clonixinate, cisapride, omeprazole and ciprofloxacin, without improvement in 24 hours. She attended again with a 12-hour history of increased pain, accompanied by nausea without vomiting, anorexia, non-quantified fever and pain reduction on left-lateral position with legs flexed toward the abdomen/chest; she denied genitourinary or genital symptoms; last evacuation had been 16 hours prior, in small amount and with normal characteristics.

Findings on physical examination were: blood pressure at $110 / 60 \mathrm{mmHg}$, heart rate 112 beats per minute, respiratory rate 20 breaths per minute, temperature $38.2^{\circ} \mathrm{C}$, neurologically intact, no cardiopulmonary alterations, protuberant abdomen due to subcutaneous fat, Pfannenstiel-type scar, soft, depressible; positive McBurney, Von Blumberg, psoas, heel percussion and obturator signs; negative Murphy, ureteral and pancreatic point and

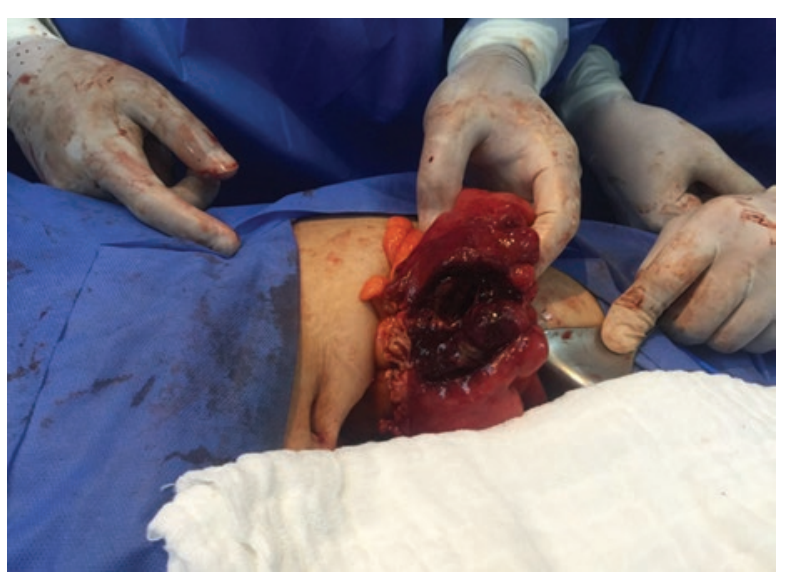

Figure 1. Sigmoid colon perforation.

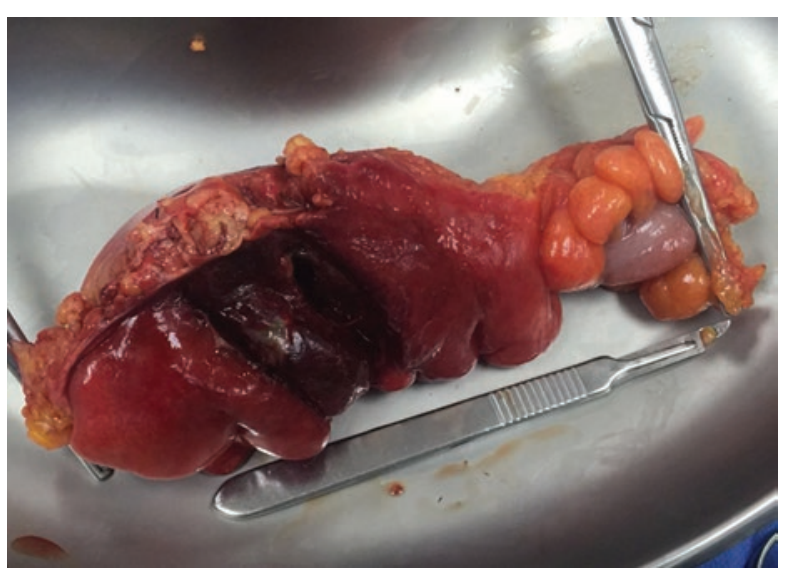

Figure 2. Sigmoid colon segment.

Giordano signs; intact extremities, and no neurovascular compromise.

Blood count: white blood cells $16.8 \times 10^{3} / \mathrm{L}$, neutrophils $78.2 \%$, hemoglobin $9.1 \mathrm{mg} / \mathrm{dL}$, platelets 589,000 , negative pregnancy test.

Exploratory laparotomy was performed due to the suspicion of appendicitis, with the following findings: cecal appendix with normal characteristics, abscess in the sigmoid colon region of approximately $100 \mathrm{~mL}$, sigmoid colon with $10 \times 10 \mathrm{~cm}$ volume increase, with reddish-brown adipose tissue, with fibrinous exudate, and two 3.5 and $5-\mathrm{cm}$ injuries breaking tissue continuity on its cross-sectional surface (Figs. 1 and 2). Sigmoidectomy was carried out, with distal stump Hartmann pouch-type closure and end colostomy.

Pathology report: sigmoid colon serous and adipose tissue with presence of tubular endometrial glands with no atypia on their epithelium, surrounded by fusocellular endometrial stroma without atypia; endometrial glands epithelium positive for estrogen nuclear receptor and cytokeratin 7; endometrial stroma positive for 
CD 10; and vascular endothelium positive for CD 34, whereby endometriosis foci were confirmed.

\section{Discussion}

Endometriosis is a pathology that is considered to be benign, but may have an aggressive behavior and cause serious complications. Intestinal endometriosis poses an important diagnostic challenge for surgeons, gynecologists and gastroenterologists in their practice.

Intestinal serosa and muscle layers are commonly affected, while transmural participation in the mucosa is rare. Mucosal compromise constitutes the most severe form of intestinal endometriosis. Most common localizations are the rectum and the sigmoid colon $(73 \%)$, while involvement of the small intestine (2$16 \%)$, the appendix (3-18\%), the cecum $(2-5 \%)$ and the ileum $(4.1 \%)$ is exceptional ${ }^{2,5}$.

Setubal and Sidiropoulou ${ }^{6}$ reported three cases of endometriosis, all in pregnant patients, out of which two were known to have a history of endometriosis and one had no relevant history. In all of them, initial symptoms were acute events of abdominal pain in the pelvic region and required exploratory laparotomy. In all three cases, sigmoid colon involvement was found and resection of the compromised segment was carried out.

Galazis et al. ${ }^{5}$ reported the case of a non-pregnant patient presenting with a 1-month history bloating, nausea and vomiting, who referred sudden pain in the left iliac fossa with irradiation to the suprapubic region, and a history of laparoscopy for endometriosis. She underwent exploratory laparotomy, with sigmoid colon perforation being found, which prompted the performance of left hemicolectomy and end colostomy.

Garg and Bagul ${ }^{7}$ reported the case of a female patient with a 10-day history of colicky pain in the left flank and iliac fossa; she had suffered from endometriosis in the past. She underwent exploratory laparotomy and an endometriotic mass was found in the left ovary and fallopian tube, with colon sigmoid involvement and perforation. Left hemicolectomy and proximal colostomy were performed, as well as endometriotic mass and left annex resection.

The patient in our case, unlike most reported cases, had no past history of endometriosis, which made suspicion more difficult. Diagnosis can be difficult, since most times there is no history suggestive of endometriosis, signs and symptoms are unspecific, and patients often present with acute abdomen, which requires exploratory laparotomy.

\section{Conclusion}

This is a rare, but serious complication. Perforation mainly occurs associated with pregnancy, at its conclusion and in the puerperium, and there are very few reported cases with no association with pregnancy. Management should be multidisciplinary. This disease should always be borne in mind as a suspicion in the presence of acute abdomen in a woman of childbearing age and with a history of intermittent gastrointestinal symptoms. A past history of endometriosis or coexistent gynecological symptoms should increase the index of suspicion, and laparoscopy prior to formal laparotomy should be considered if there is evidence of intestinal perforation.

\section{References}

1. Costa A, Sartini A. Deep endometriosis induced spontaneous colon rectal perforation in pregnancy: laparoscopy is advanced tool to confirm diagnosis. Case Rep Obstet Gynecol. 2014;2014:907150.

2. Albareda J, Albi MV, Sosa G, Cano A, Macello ME, Albi Martin B. Puerperal ileal perforation secondary to endometriosis: case report and literature review. Taiwan J Obstet Gynecol. 2016;55:121-4.

3. Dimoulios P, Koutroubakis IE, Tzardi M, Antoniou P, Matalliotakis IM, Kouroumalis EA. A case of sigmoid endometriosis difficult to differentiate from colon cancer. BMC Gastroenterol. 2003;3:18.

4. Tong YL, Chen Y, Zhu SY. lleocecal endometriosis and a diagnosis dilemma: a case report and literature review. World J Gastroenterol. 2013;19:3707e10.

5. Galazis N, Arul D, Wilson J, Pisal N. Bowel endometriosis. BMJ Case Rep. 2014. pii: bcr2013202140. doi: 10.1136/bcr-2013-202140.

6. Setubal A, Sidiropoulou Z. Bowel complications of deep endometriosis during pregnancy or in vitro fertilization. Fertil Steril. 2014;101:442-6.

7. Garg NK, Bagul NB. Intestinal endometriosis - a rare cause of colonic perforation. World J Gastroenterol. 2009;15:612-4. 